\title{
減衰定数一定の弾塑性応答スペクトルによる1995年兵庫県南部地震での 建物被害の再検証 \\ REVIEW OF DAMAGE TO BUILDINGS DURING 1995 HYOGOKEN-NANBU EARTHQUAKE BY ELASTO-PLASTIC RESPONSE SPECTRUM WITH CONSTANT DAMPING FACTOR
}

\author{
小川好* \\ Yoshimi OGAWA
}

\begin{abstract}
Three noticeable cases of damage during the 1995 Hyogoken-Nanbu earthquake are reviewed; the damage rate of reinforced concrete buildings in Kobe city, the behavior of the Shin-Nagata high-rise residential building, the fractures of columns of high-rise buildings in Ashiyahama Seaside town. In these cases, the predominant periods of ground motions are considerably longer than the natural periods of buildings and resonance is not expected. These phenomena are examined by a proposed response spectrum of elasto-plastic system with constant damping factor and explained as transitions of natural periods of buildings. This method gives appropriate estimates of an increase in period with an increase in amplitude.
\end{abstract}

Keywords: Natural Period of Building, Response Spectrum, Elasto-Plastic Response, Visco-Elastic Response, Damping Factor, Hyogoken-Nanbu Earthquake 建物固有周期, 応答スペクトル, 弾塑性応答, 粘弾性応答, 減衰定数, 兵庫県南部地震

\section{1.はじめに}

耐震工学は, 言うまでもなく, 過去の地震被害からきわめて多く の事柄を学んできている。1995 年の兵庫県南部地震も例外ではなく, 発生した事象については多岐にわたって議論されており, 得られた 知見は寸でに数多く報告されている。しかし, 被害のなかにはメカ ニズムが必ずしも十分に説明されているわけではないと考えられる 事例も含まれていることから, 本論では代表的な次の 3 例について 新たな解釈を加えることで，再検討を試みる。

第 1 の例は，コンクリート系建物の階数と被害との関係について の統計結果である。林ら ${ }^{1)}$ の解析結果によれば, ピロティー建物を 除く一般建物が中破以上になるかどうかは建物階数の影響が大きく, 7 階以上の建物は 6 階以下の建物に比べて明らかに被害率が大きか ったとされている。建築物の減衰 ${ }^{2}$ や建築構造物の振動実験 ${ }^{3)}$ によ れば, 7 階のコンクリート系建物の固有周期は 0.4 秒程度であり, 兵庫県南部地震での 1 秒から 2 秒という卓越周期とは大きく異なる。 一方, 強震記録が得られている新長田駅前の高層 SRC 造建物 ${ }^{4}$ は, 震度VIIの激震地に立地しているにもかかわらず，震災直後の被災度 区分判定では軽微と判定されている。この建物の微小変形時での固 有周期は 1 秒程度であり, 当然, 地震動と共振したと考えられるこ とから，第 2 の検討例とした。

第 3 の事例は, 芦屋浜高層住宅の被害 ${ }^{5}$ である。よく知られてい るように，この高層住宅群は「工業化工法による芦屋浜高層住宅プ ロジェクト提案競技」により選定されて 1979 年に完成したもので, 14 階と 19 階, 24 階, 29 階の 4 タイプ 52 棟が同一の構造システム で建設されている。兵庫県南部地震ではボックス柱が脆性破断する という特徵的な被害が発生したことで注目をあびたが, 被害は階数
タイプによって大きく異なっていた。ボックス柱の破断は 24 階のタ イプでは 11 棟中 10 棟（合計 33 箇所），19階タイプでは 17 棟中 16 棟（30 箇所）で発生しているのに対して，29 階タイプ 3 棟には全く 発生していない。また，14 階タイプ 21 棟では 3 棟（合計 6 箇所） と発生が少ないだけでなく, 14 階タイプのみ 6 棟からなる 2 ブロッ クはボックス柱, 大梁, ブレース, 共用階卜ラス寸べて無被害であ った。プロジェクトの完成に先立って実施された振動実験 ${ }^{6)}$ で求め られた固有周期の実験式によれば, 14 階と 19 階, 24 階, 29 階の固 有周期はそれぞれ 0.8 秒と 1.1 秒， 1.4 秒， 1.7 秒となり, 被害の差 を固有周期の違いだけから単純に説明することはできないであろう。

これらの事例は，いずれも建物固有周期と地震動の卓越周期との 関係に関連したものである。被害をうけた建物の固有周期が付近で 観測された強震記録の卓越周期とは必ずしも一致しないという点に ついては, 兵庫県南部地震も含め, 寸でに境ら ${ }^{7,8)}$ によって報告さ れている。また, 建物が微小変形時の固有周期よりも周期の長い地 震動に対して被害を受けやすいことの解釈としては, 構造体の非線 形化に伴う建物固有周期の長周期化をとえば9)や, 長周期化を応答塑性

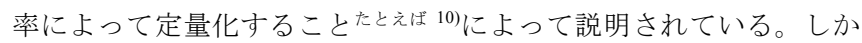
し，建物の非線形化を長周期化の原因とすることは，構造体の相当 な損傷を前提としており，地震動と建物との周期はほぼ一致したに もかかわらず被害が軽微であった事例をうまく説明することができ

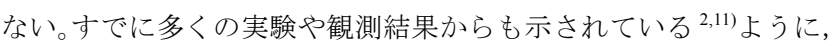
建物周期の長周期化は構造体が塑性化するよりはるかに小さな振幅 レベルから生じている。耐震設計上必要とされる建物の固有周期は, 言うまでもなく建物が強震動にさらされたときの周期であることを 考えると，このときの周期をいかに合理的に推定するかはきわめて

* 東京都土木技術支援・人材育成センター 主任・博士(工学) Research Engineer, Civil Engineering Support and Training Center, Tokyo Metropolitan Government, Dr. Eng. 
重要な課題である。

筆者は 1 自由度質点系の減衰を粘性減衰ではなく摩擦に起因する 履歴減衰であると考えることで, 振幅の大きさと固有周期の伸びと を定量的に求める方法を提案している。また, 兵庫県南部地震以降 に観測された強震記録について, 建物固有周期の遷移を考慮した応 答スペクトルの卓越周期は, 木造建物の被害の大小をうまく説明す ることを指摘した ${ }^{12)}$ 。本論では, 同様の議論をコンクリート系およ び鉄骨系の高層建物での被害の検討に適用する。そのため, 次の章 では減衰定数を一定とする履歴減衰の導入を概説するとともに, 1 自由度系の応答解析での実際の計算法とプログラムについて, やや 詳細に解説する。

\section{2. 減衰定数一定の弾塑性応答スペクトル \\ (1) 復元力特性の定式化}

弾塑性系の履歴による減衰定数が粘弾性系の減衰定数と同様に一 定であり， 1 周期の間に消費されるエネルギー $\Delta W$ と弾性要素に貯 えられる最大ポテンシャルエネルギー $W$ との比によって定義される と考える ${ }^{13)}$ 。いま, 変位を $x$ とする骨格曲線 $y=F(x)$ を図 1 のように 規定し, 骨格曲線と履歴曲線との関係が Masing の規則を満足すると 仮定する。このとき, 変位振幅が $X(X>0)$ のヒステリシスループ での減衰定数 $h$ は(1)式で与えられる。

$$
\begin{aligned}
h & =\frac{1}{4 \pi} \cdot \frac{\Delta W}{W} \\
& =\frac{1}{4 \pi} \cdot \frac{8\left[\int_{0}^{X} F(x) d x-\frac{1}{2} X \cdot F(X)\right]}{\frac{1}{2} X \cdot F(X)}
\end{aligned}
$$

いま, 減衰定数 $h$ の媒介変数 $h^{\prime}$ を

$$
h^{\prime}=\frac{h}{1-\pi h / 2}
$$

として(1)式に代入することで，骨格曲線 $F(x)$ は

$$
F(x)=C \cdot x^{\frac{1}{1+\pi h^{\prime}}} \quad, \quad \log [F(x) / C]=\frac{1}{1+\pi h^{\prime}} \log x
$$

と導かれる ${ }^{12)}$ 。ここで， $C$ は骨格曲線の全体的な勾配（水平剛性） を規定する定数である。なお，(2)式で規定される $h^{\prime}$ は単なる媒介 変数ではなく, 弾塑性系の減衰定数 (ここでは塑性減衰定数と呼ぶ) として物理的な意味をもつ ${ }^{14}$ が，一般的ではないことから，以下の 議論では粘性減衰定数 $h$ を減衰定数として用いることとする。

減衰定数を変化させたときの骨格曲線の復元力特性を, 図 2 に示 す。ここで(3)式の定数 $C$ は $1 \mathrm{~N}$ とている。この図に見られるよう に, 両対数軸上で直線となる骨格曲線が作る復元力特性は一定の減 衰定数を与えることになり, 減衰定数が大きくなるに従って勾配は 小さくなる。また, 単位の変位 $(1 \mathrm{~m})$ では減衰定数に関わらず一定值 $C$ をとることから，減衰定数の変化に対して不動点となっている。 不動点より小さな変位では減衰定数が大きいほど復元力は大きくな るのに対して，この点より大きな変位では逆転する。

\section{（2） 1 自由度質点系の非線形応答解析}

地震動加速度 $\ddot{y}$ に対する弾塑性応答は(4)式を時刻歴に解析する ことで得られる。

$$
m \ddot{x}+Q(x)=-m \ddot{y}
$$

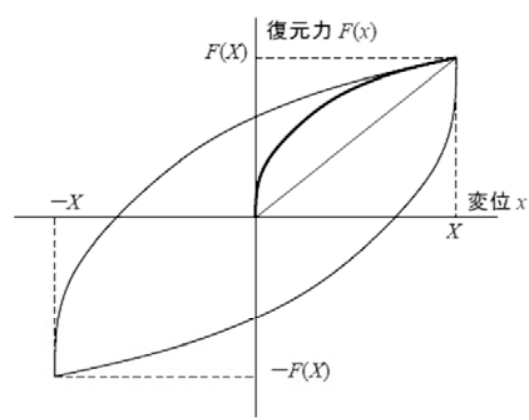

図 1 骨格曲線 $y=F(x)$ と履歴曲線との関係

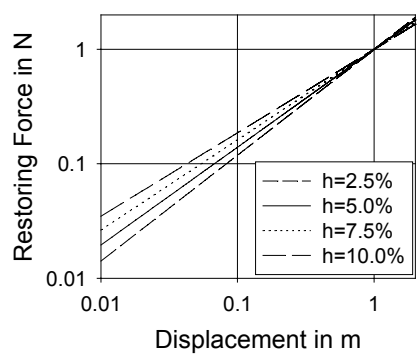

(a) 対数での表示

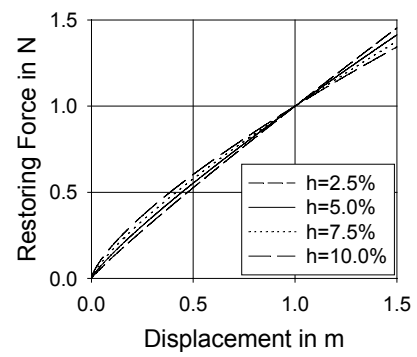

（b）実数での表示
図 2 減衰定数が一定となる復元力特性

ここで $m$ は質点系の質量であり，単位質量 $(1 \mathrm{~kg})$ に基準化する。ま た $Q(x)$ は復元力であり, (3)式で求めた骨格曲線をもとに設定される が，ヒステレシスループ上の值である復元力 $Q(x)$ は, 図 1 に例示寸 るように変位 $x$ が変化する方向によって異なる曲線上をたどること から, そのまま演算に用いるのは容易ではない。そこで, (3)式を Iwan の力学的モデル ${ }^{15}$ に変換した演算要素に変位 $x$ を入力することで, 骨格曲線とヒステリシスループ上の復元力を求めている。

Iwan モデルは図 3 に示すように, 複数のバネ（図 3 の $f$ ) とスラ イダー（図 3 の）から構成されるもので, 対象と寸る骨格曲線が 1 価の単調な増加関数であり, その接線勾配が原点から離れるに従 って単調に減少するとき, 常に Masing の規則を満足したヒステリシ スループを描くことができる。

応答解析のフローを図 4 に示寸。図中のサブルーチン SYSCOMPO と TIMESTEP については, 論文末に APPENDIX 1 としてソースリス 卜を追記している注1)。図 3 の Iwan モデルは, 設定した復元力の最 大值を超えると完全塑性を示すが, 復元力の最大值はあらかじめ知 ることができない。このため, 降伏強度の初期值を $30 \mathrm{~N}$ として計算 し, 相対変位が降伏強度に対応する降伏点の変位を越える場合は, 降伏強度を増大させた Iwan モデルを再構成している。また, 計算さ

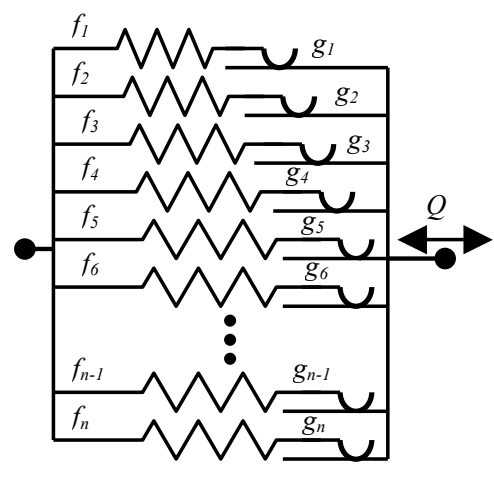

図 3 Iwan ${ }^{15)}$ の並列型モデル 
れた最大慣性力が設定した復元力よりも小さすぎると, 骨格曲線の 離散化による誤差が大きくなることから，この比が 3 分の 1 以下に なったときは最大復元力をより小さく設定してモデルを再構成した。 骨格曲線の離散化は, 最大復元力まで変位について等間隔に 1000 分割している。

図 2 からも理解されるように, 提案寸る弾塑性 1 自由度質点系に は, 通常の粘弾性 1 自由度質点系の固有周期に相当する周期が存在 しない。後述するように, 弾塑性 1 自由度質点系の固有周期として は最大応答時での等価固有周期を採用するが，この周期はあらかじ め知ることができない。そのため, 不動点である単位の変位 $L(1 \mathrm{~m})$ での割線弾性率から計算される周期を設定固有周期 $T_{S E T}$ として(5) 式で定義し, この周期をもとに(4)式の復元力特性 $Q(x)$ の基となる骨 格曲線を決定する。

$$
T_{S E T}=2 \pi \sqrt{\frac{m}{(C / L)}}
$$

設定固有周期 $T_{S E T}$ は減衰定数にかかわらず一定となるとともに, 単位の変位である $1 \mathrm{~m}$ は強震時の最大変位とオーダーとして一致す ることから，イメージしやすい周期である。

時刻歴解析は時刻 $t$ での質点系の加速度と変位を与件として, 時 間刻み $\Delta t$ を $0.001 \mathrm{sec}$ としたときの $t+\Delta t$ での変位を線形加速度法で 求め, (4)式のつりあいから $\Delta t$ 間の加速度増分 $\Delta \ddot{x}$ を計算する。この $\Delta \ddot{x}$ から再び変位を計算し, (4)式に代入する演算をくり返すことで 収束計算を行う。収束条件としては, 連続した 2 回の加速度増分量 の比が $0.001 \%$ 以内, または差が $1.0 \times 10^{-5} \mathrm{~m} / \mathrm{sec}^{2}$ 以内に収まった結果 を真としている。

\section{（3）減衰のメカニズムと減衰定数の振幅依存性}

建物の減衰の要因としては, 建物自体の構造的な減衰と地盤の内 部摩擦，地下逸散による減衰にわけることができる。このうち，建 物の構造的な減衰について, Lagomarsino $\left.{ }^{13}\right)$ は構造材料に固有な減衰 と構造接合部の摩擦による減衰に分類し， RC 造などの脆性材料で は微小なクラック表面での摩擦によって減衰が発生するのに対して 構造接合部での摩擦による減衰はボル卜接合された $\mathrm{S}$ 造に顕著であ るとしている。

ボルト接合が $\mathrm{S}$ 造の減衰に与える影響は, 曽田ら ${ }^{16)}$ にって実験 的に調べられている。曽田らは溶接接合と高力ボルト接合の小型鋼 製フレームモデルを用いて弾性範囲で加振実験をおこなった結果, 減衰はボルト接合の方が高く, 振幅依存性を示すとしている。この ような巨視的なすべりが生じる前段階の微小なす心゙りは，「予す心゙ り」あるいは「micro-slip」注2)と呼ばれるもので，工作機械などの分 野では以前から研究されている。小泉ら ${ }^{17)}$ はボルト接合部に接線方 向荷重をくり返し載荷した結果， 1 周期間の散逸エネルギーは荷重 の大きさに対して両対数グラフ上で直線的に増加し, 指数の值は 1.8 〜2.8の範囲にあるとしている。一方, Sandia 国立研究所での最近の 一連の実験結果 ${ }^{18)}$ によれば，この指数は 2 よりも大きな値となって おり, 減衰定数は振幅に依存して増大寸ることになる。また, 小泉 らの実験と Sandia国立研究所の実験に共通する特徽的な事象として, 散逸エネルギーは載荷履歴の影響をうけ, 同一の荷重でも初期の載 荷くり返しでは散逸エネルギーが大きな点があげられる。このこと から，建物が初めて遭遇するようなレベルの強震動では，減衰定数 は通常計測されている值より大きくなる可能性がある。

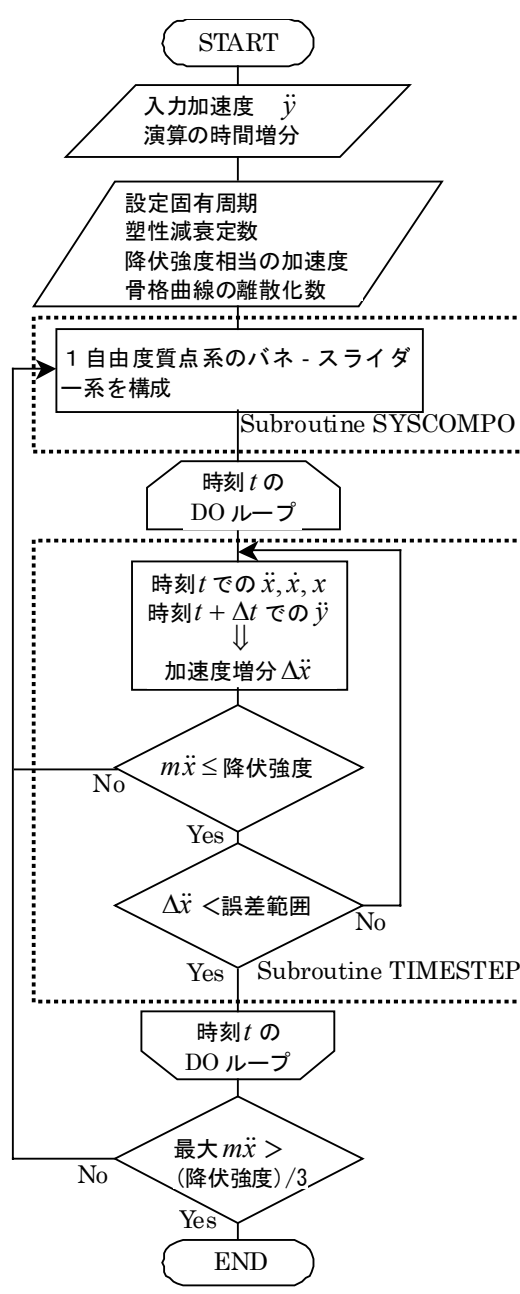

図 4 応答解析のフローチャート

脆性構造材料としてのコンクリートの減衰特性を知る上で，吉本 の実験成果の報告 ${ }^{19}$ は示唆に富む。吉本によると, コンクリートの 応力ーひずみ曲線を両対数目盛で図示すると, いくつかの折れ点注 3)を結ぶ直線で表示され, 直線の勾配はひずみが大きくなるにした がって低下していくとしている。コンクリートの応力ーひずみ曲線 が両対数軸上で直線関係にあることは, 本論で考えている復元力特 性と調和する実験事実である。また，ひずみの増大にしたがって折 れ点ごとに勾配が低下していくことは，コンクリート構造物もゆれ の振幅にしたがって減衰定数が大きくなることを示唆している。

本論は 1 自由度質点系の応答スペクトルについて，減衰が一般的 な粘性によるものではなく, 摩擦に起因する履歴減衰と考えたとき に，どのような違いが現れるか考察することを目的としている。ま た, 解析的にも減衰定数の振幅依存性を取り入れることができない ため, 減衰定数を一定として議論を進めるが, 被害との関係から推 定される減衰定数は, 微小振幅時に測定されている值よりも大きく なる可能性がある。

\section{3. 兵庫県南部地震での地震動の応答スペクトル}

1995 年兵庫県南部地震の際に莫合と神戸海洋気象台, 鷹取で観測 された地震動について, 減衰定数を $5 \%$ (粘性減衰定数 $h=5 \%$, 塑性 減衰定数 $\left.h^{\prime}=5.426 \%\right)$ としたときの応答スペクトルを図 5 に示す。 ここで消費エネルギー・スペクトルは，入力地震動が終了するまで 

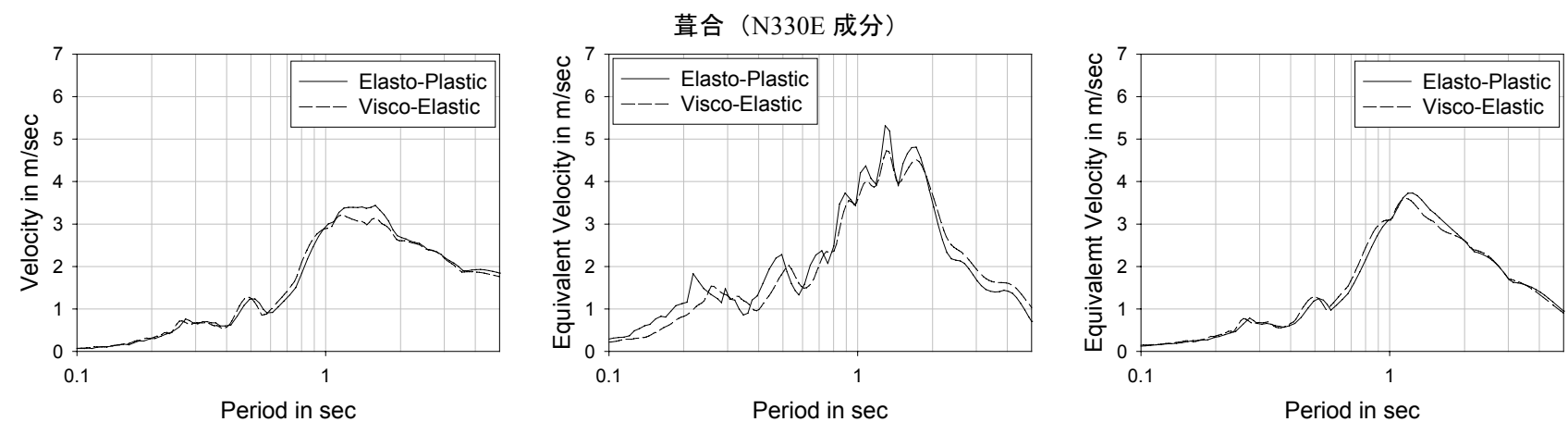

神戸海洋気象台（NS 成分）
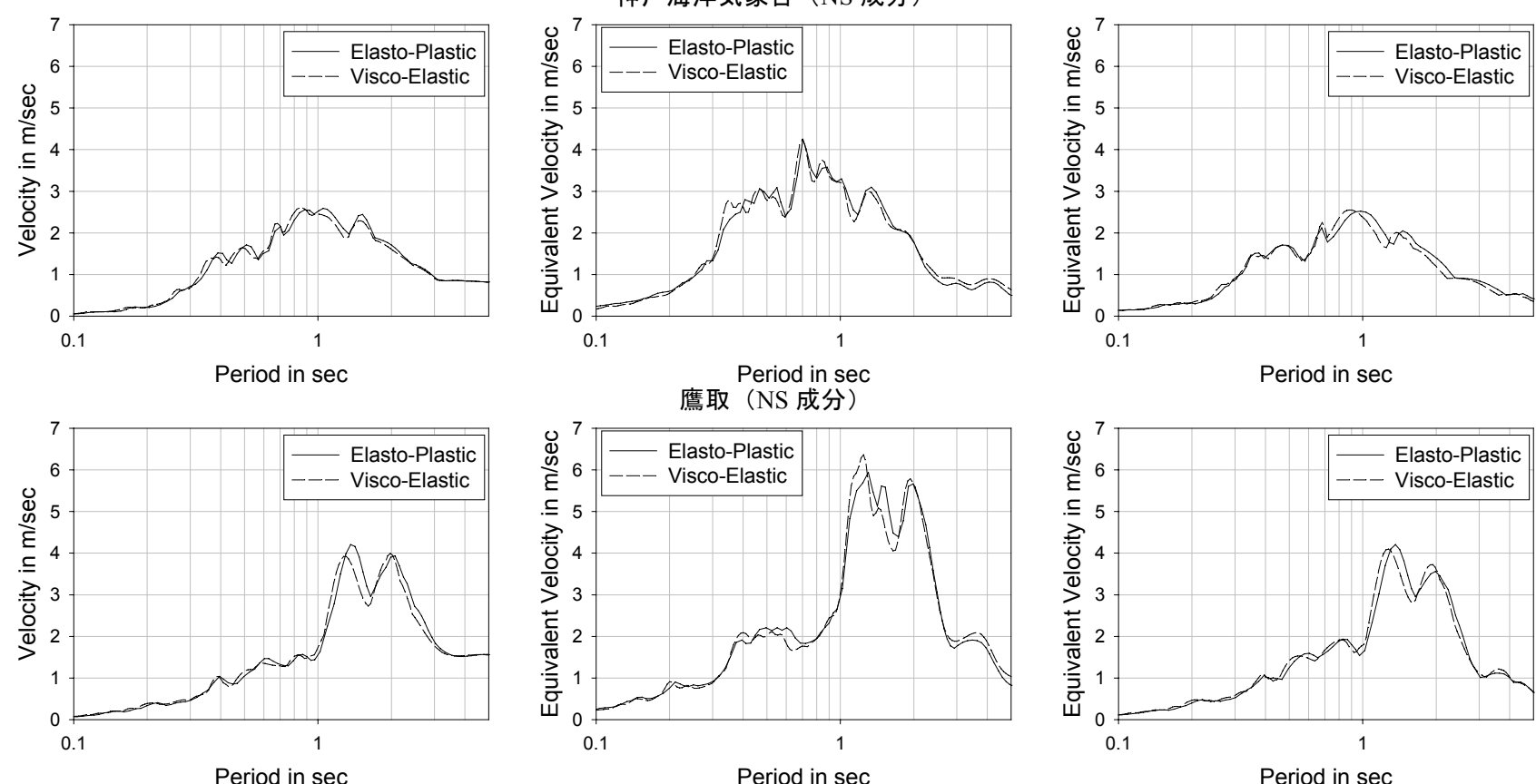

(A) 速度応答スペクトル

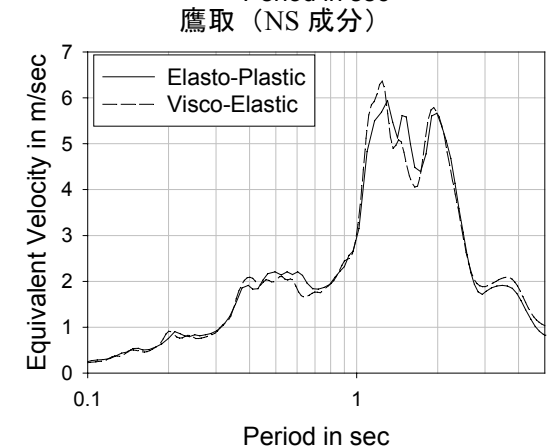

（B） 消費エネルギー・スペクトル

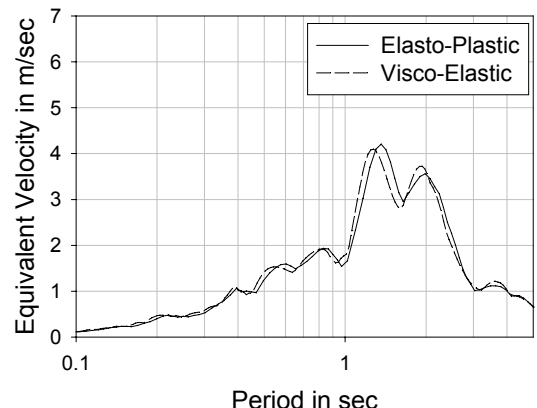

（C）弾性エネルギー・スペクトル

図 5 弾塑性スペクトルと粘弾性スペクトルとの比較（減衰定数 $h=5 \%$ )

に, 弾塑性系では Iwan モデルのスライダーが移動することで, 粘弾 性系では粘性減衰によってそれぞれ消費されるエネルギーをもとに， このエネルギーが質点の運動エネルギーと等価と考えたときの速度 である。同様に, 弾性エネルギー・スペクトルは, 弾塑性系では Iwan モデルのバネに蓄えられる最大エネルギーの, 粘弾性系では線形バ ネに蓄えられる最大エネルギーの速度換算值である。

前述したように，弾塑性系の固有周期としては最大応答時の割線 弾性率で定義される等価固有周期 $T_{E Q}$ を採用する。また, 粘弾性系 では非減衰固有周期 $T_{U D}$ を使用するが, 本論では特に区分する必要 がないときは固有周期 $T$ と表記する。弾塑性応答では最大復元力は 最大相対変位と同時刻に骨格曲線上に発生し, このとき絶対加速度 も最大值となることから, 等価固有周期 $T_{E Q}$ は(6)式で表される。

$$
T_{E Q}=2 \pi \sqrt{\frac{x_{\max }}{a_{\max }}}=2 \pi\left(\frac{m}{C}\right)^{\frac{1+\pi h^{\prime}}{2}} a_{\max }^{\frac{\pi h^{\prime}}{2}}=2 \pi\left(\frac{m}{C}\right)^{\frac{1}{2}} x_{\max }^{\frac{\pi h^{\prime}}{2\left(1+\pi h^{\prime}\right)}}
$$

ここで $x_{\max }$ と $a_{\text {max }}$ は最大相対変位と最大絶対加速度の振幅值である。

図 5 に見られるように, 減衰定数が $5 \%$ では弾塑性系と粘弾性系 の応答スペクトルはほぼ一致している。図 6 には, 莫合の解析例か ら弾塑性系の等価固有周期に粘弾性系の固有周期を合わせたときの 時刻歴応答を示す。図6(A)の速度応答波形は, 強制振動の部分では 弾塑性系と粘弾性系の応答はほぼ同一であるが, 自由振動が卓越す
る後続の部分では弾塑性系の応答の位相が粘弾性系よりも速くなる とともに, 振幅にも違いが見られる。これは, 弾塑性系では振幅が 小さくなると周期も短くなるためである。図 6(B)に示した消費エネ ルギーの時刻歴についても, 主要動部分では両者はほとんど一致し ているが, 後続部分では微小な差が認められる。同様に(C)の復元力 特性についても, 最大変位のループは両者がかなりよく一致してい るのが見られる。

弾塑性応答スペクトルと粘弾性応答スペクトルがきわめてよく一 致するということは, 非線形応答である弾塑性応答スペクトルが線 形的に挙動することを意味している。図 7 はこの関係を見るために, 入力波形の振幅を $1 / 10$ から 1/10000 まで順次低減したときの様子を 比較したもので, 図の $(\mathrm{A})$ のよう周期を等価固有周期 $T_{E Q}$ にとると, 振幅の夕が倍率にしたがって低下寸るだけでスペクトルの卓越周期 は一致し, 形状も同一となる。このことは, 提案する弾塑性応答ス ペクトルは等価固有周期で表したとき, 固有の大きさがないという フラクタルな性質があることを意味している。そして，このフラク タル的性質は, 復元力が(3)式のべき乗の関数によって与えられてい ることに起因している。

一方, 個別の 1 自由度質点系が入力波形の振幅の減少にどのよう に応答するかを見たのが設定固有周期図 $T_{S E T}$ で表示した図の(B)で ある。図 2 の復元力特性からも理解されるように, 個別の 1 自由度 
質点系は，入力波形の振幅が小さくなるにしたがって短周期に応答 するようになるため, 入力波形の振幅が小さくなるにしたがって卓 越する設定固有周期は長周期側に移行する。

提案する弾塑性 1 自由度質点系は, 入力する地震動の振幅が大き ければ長周期に，小さければ短周期に応答する。いま，異なる応答 振幅を $A_{1}$ と $A_{2}$ に, このときの等価固有周期を $T_{E Q, 1}$ と $T_{E Q, 2}$ とおくと, 等価固有周期の比は(6)式を変形した(7)式

$$
\frac{T_{E Q, 1}}{T_{E Q, 2}}=\left(\frac{A_{1}}{A_{2}}\right)^{\alpha}
$$

で与えられる。ここで $\alpha$ は振幅 $A$ が絶対加速度と相対速度, 相対変 位に対してそれぞれ $\pi h^{\prime} / 2$ と $\pi h^{\prime} /\left(2+\pi h^{\prime}\right), \pi h^{\prime} / 2\left(1+\pi h^{\prime}\right)$ となる。

建物の減衰を摩擦に起因する履歴減衰と考えるか粘性減衰と考え るかによって生じる最大の違いは, 応答するときの周期に振幅依存 性があるかないかという点にある。一方, 建物の固有周期として軒 高や階数と関連づけられている值は, 設計值を除けば微小振幅で測 定された振動特性から求められている ${ }^{2,3)}$ 。のため, 提案する弾塑 性応答スペクトルの卓越周期と建物の固有周期を比較しょうとする と, 図 5 の等価固有周期を微小変形時の等価固有周期に変換しなけ れば，共振の有無を判断できないことになる。

微小振幅時の等価固有周期を疑似弾性固有周期 $T_{P E}$ と呼ぶことに すると， $T_{P E}$ は設定固有周期 $T_{S E T}$ との間に(8)式

$T_{P E}=T_{S E T}\left(\frac{x_{0}}{L}\right)^{\frac{\pi h^{\prime}}{2\left(1+\pi h^{\prime}\right)}}=T_{S E T}\left(\frac{T_{S E T}}{2 \pi} \frac{v_{0}}{L}\right)^{\frac{\pi h^{\prime}}{2+\pi h^{\prime}}}=T_{S E T}\left[\left(\frac{T_{S E T}}{2 \pi}\right)^{2} \frac{a_{0}}{L}\right]^{\frac{\pi h^{\prime}}{2}}$

の関係があることが(5)式と(6)式，(7)式から導かれる。ここで $x_{0}$ と $v_{0}, a_{0}$ はそれぞれ微小振幅時の相対変位と相対速度, 絶対加速度の 振幅值， $L$ は単位の変位 $(1 \mathrm{~m})$ である。疑似弾性固有周期 $T_{P E}$ で表 示したスペクトルは, 図 7 に見られるように, 設定固有周期 $T_{S E T}$ と 同様に入力する振幅の大きさにしたがって変化する。

疑似弾性固有周期 $T_{P E}$ は(7)式から直接, (9)式

$T_{P E}=T_{E Q} \cdot\left(\frac{x_{0}}{x_{\max }}\right)^{\frac{\pi h^{\prime}}{2\left(1+\pi h^{\prime}\right)}}=T_{E Q} \cdot\left(\frac{v_{0}}{v_{\max }}\right)^{\frac{\pi h^{\prime}}{\left(2+\pi h^{\prime}\right)}}=T_{E Q} \cdot\left(\frac{a_{0}}{a_{\max }}\right)^{\frac{\pi h^{\prime}}{2}}$

としても求められる。ここで $x_{\max }$ と $v_{\max }, a_{\max }$ は最大相対変位と最大 相対速度, 最大絶対加速度の振幅值である。(9)式の関係は等価固有 周期 $T_{E Q}$ で表示した弾塑性応答スペクトルと粘弾性応答スペクトル がよく似ていることを利用して, 粘弾性応答スペクトルを疑似弾性 固有周期で表示するのに利用できる。

疑似弾性固有周期 $T_{P E}$ を求める際の微小振幅值としては, 前回の

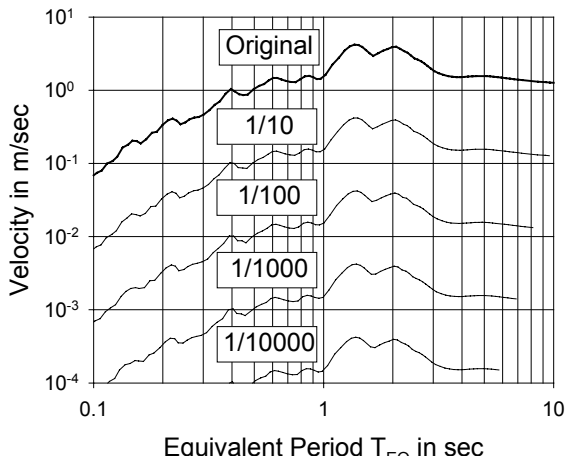

(A) 等価固有周期による応答スペクトル

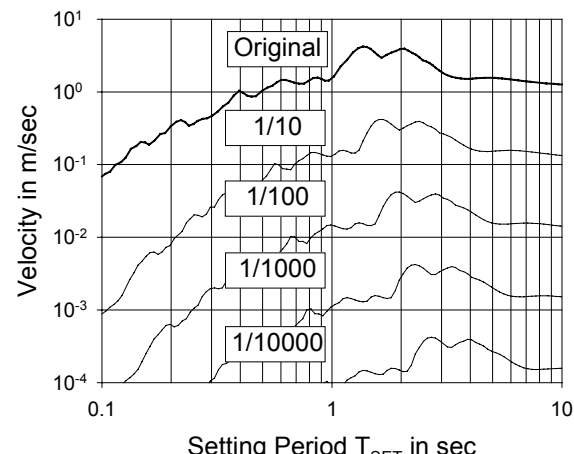

(B) 設定固有周期による応答スペクトル

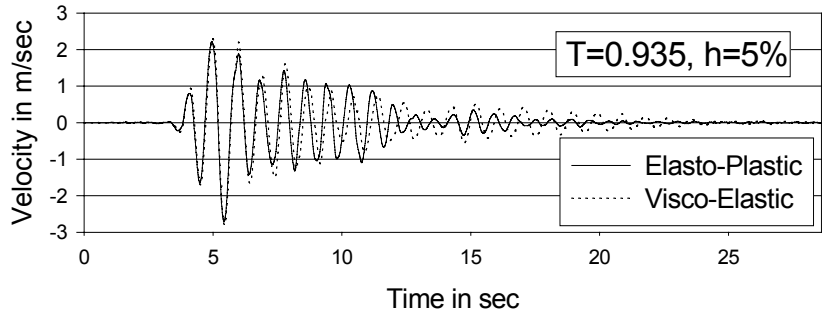

(A) 速度の時刻歴

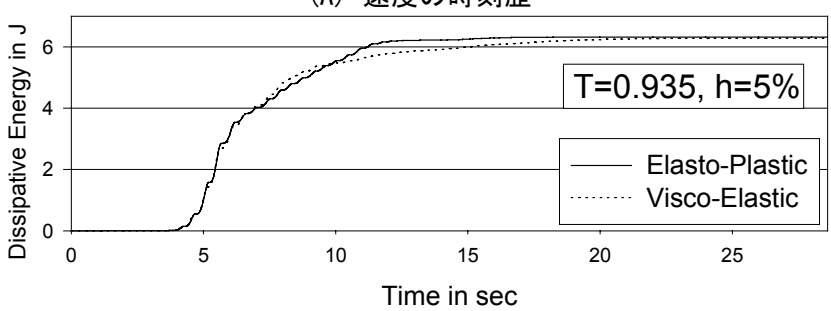

(B) 消費エネルギーの時刻歴

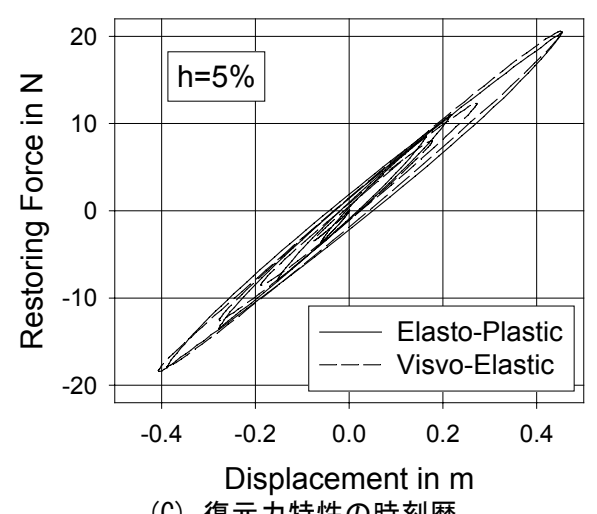

(C) 復元力特性の時刻歴

図 6 莫合の時刻歴応答（周期 $T=0.935$ 秒, 減衰定数 $h=5 \%$ )

報告 ${ }^{12)}$ と同様に， $1 \times 10^{-4} \mathrm{~m} / \mathrm{sec}$ (10mkine) とする。この值は，建築 物の減衰 ${ }^{2}$ の「実測減衰データベース」に掲載されている速度振幅 の常時微動のうち, 特異值を除いた 33 データの平均值 $1.9 \times 10^{-4} \mathrm{~m} / \mathrm{sec}$ (変動係数 0.64)をもとに設定したものである。建物固有周期を測定 する振動実験では, 微小振幅といっても常時微動より大きな範囲の 振幅も含まれていると考えられるが，実測データから得られた建物 固有周期と振幅との関係には未解明の部分も多いことから，この值 を今回も採用寸る。しかし，(7)式からも明らかなように，疑似弾性 周期に対応する微小振幅值の大小が周期に与える影響は必ずしも大 きくない。減衰定数 $h$ が $5 \%$ （塑性減衰定数 $h^{\prime}=5.426 \%$ ）のとき, 仮に微小振幅值を $1 \times 10^{-4} \mathrm{~m} / \mathrm{sec}$ の 10 倍あるいは 10 分の 1 とした場 合でも，周期の変化はそれぞれ 0.83 倍と 1.2 倍程度である。

図 7 入力地震動の振幅を低減させたときの応答スペクトルの変化（鷹取の $\mathrm{NS}$ 成分， $h=5 \%$, 疑似弾性固有周期の微小振幅 $1 \times 10^{-4} \mathrm{~m} / \mathrm{sec}$ ) 


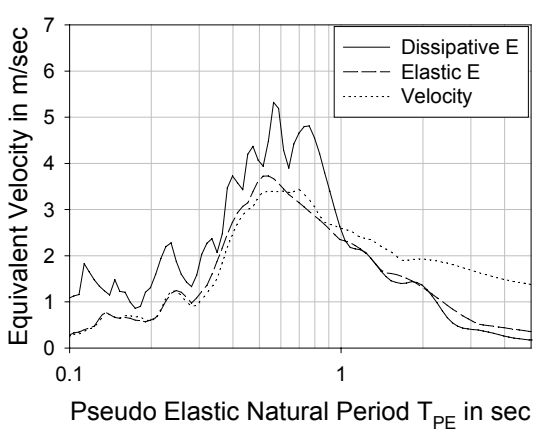

莫合 (N330E 成分)

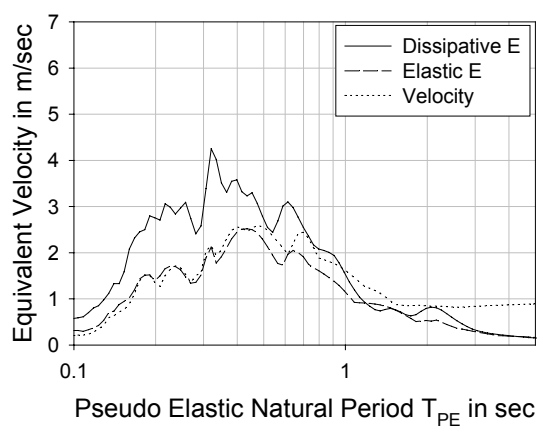

神戸海洋気象台 (NS 成分)

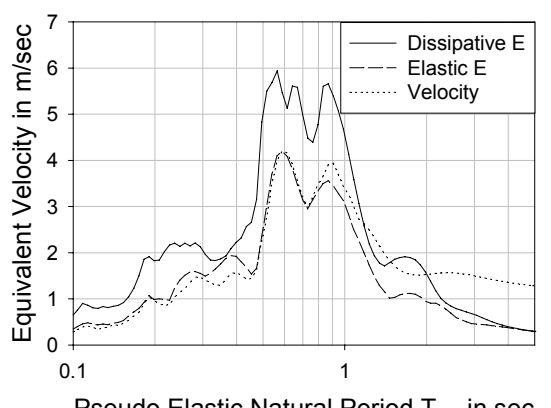

Pseudo Elastic Natural Period $\mathrm{T}_{\mathrm{PE}}$ in sec 鷹取（NS 成分）

図 8 疑似弾性固有周期で表示した弾塑性応答スペクトル（フラクタル応答スペクトル，減衰定数 $h=5 \%$ )

兵庫県南部地震の 3 地震動について, 疑似弾性固有周期 $T_{P E}$ で表 示した弾塑性応答スペクトルを図 8 に示す。等価固有周期 $T_{E Q}$ で示 した図 5 の結果に比べると, 卓越する周期帯はより短周期側に遷移 しているのが見られる。遷移の大きさは減衰定数に依存し, 図 9 に 見られるように減衰定数が大きいほど卓越する周期帯は短周期側に 現れる。なお,「疑似弾性固有周期で表示した弾塑性応答スペクトル」 という表記が長すぎるのと, 提案する弾塑性応答スペクトルには入 力振幅の大きさに対して応答周期が変わらない自己相似というフラ クタルな性質があることから, 以降この小論では「フラクタル応答 スペクトル」と呼ぶことにする。

\section{4. 兵庫県南部地震でのコンクリート系建物の階数と被害との関係}

まえがきでも述べた林ら ${ }^{1)}$ の統計解析は, 日本建築学会近畿支部 $\mathrm{RC}$ 部会による灘区・東灘区の震度VII相当地域を対象とした全数調 查結果に基づいている。7 階以上の建物が中破以上となる被害率は $23 \%$ と 6 階以下の建物の被害率 $5 \%$ に比べてかなり高く, 最大地動 速度が約 $120 \mathrm{~cm} / \mathrm{sec}$ 以上の地域にある 9 階以上の建物 75 棟の約半数 が中破以上であるとしている。さらに，この 75 棟のうち 1982 年以 降に建てられた 50 棟の $42 \%$ は中破以上であり, 新耐震設計法によ る建物でも被害率は小さくないと指摘している。また, 林らの別の 報告 ${ }^{20)}$ では, 1982 年以降に建てられた現行設計による建物でも, 階 数が高くなると被害率は高くなり，特に 8〜10 階で被害率が高いと している。

兵庫県南部地震での $\mathrm{RC}$ 建物の特徴的な被害としては, このほか に層崩壊があげられる。日本建築学会の「阪神・淡路大震災と今後

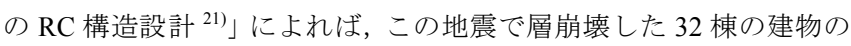
大部分は神戸市中央区の三宮駅周辺に位置しており，被害は７階か ら 10 階の建物に多かった。

建築構造物の振動実験 ${ }^{3)}$ によれば，7階のコンクリート系建物の 固有周期は 0.38 秒となる。図 9 に見られるように, 灘区・東灘区と 中央区に近い莫合のフラクタル速度応答スペクトルは, RC 建物の 一般的な減衰定数とされている $5 \%{ }^{22}$ のときに, 0.38 秒付近から応 答值が大きくなっている。また, 9 階の建物固有周期に相当する 0.49 秒よりも長周期では，スペクトルは最大振幅となっている。同様に 図 8 に示寸散逸エネルギーと弾性エネルギーについても, この周期 帯で高い值となっている。

一方, 対象地域に比較的近い神戸海洋気象台のスペクトルは, 被 害率の高い階数の周期とはあまり密接な関係は示していない。この 観測点は震度VIIの地域に含まれておらず，周辺の大破・全壊以上の

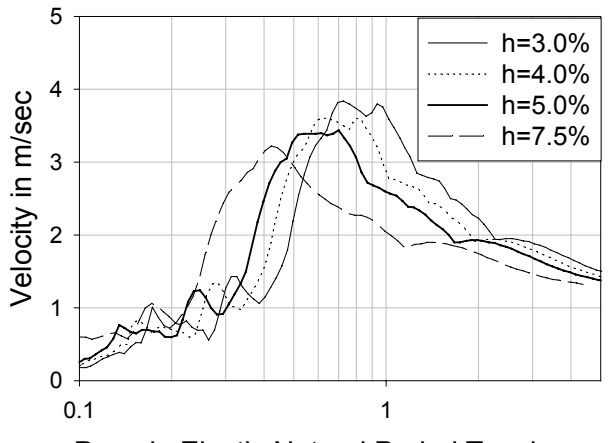

Pseudo Elastic Natural Period $\mathrm{T}_{\mathrm{PE}}$ in sec

図 9 減衰定数の違いによる擬似弾性固有周期の变化 （莫合のフラクタル速度応答スペクトル）

建物の割合も $2.5 \%$ と低い ${ }^{8)}$ ことから， RC 建物に被害を与えた地震 動を代表したものではないと考えられる。

林らは三宮地域の再現地震動と震度VII地域内の地盤条件, 仮想建 物モデル（3〜15 階の間で 3 階間隔）によって, 建物高さと建物応 答特性との関係を検討している ${ }^{1,20)}$ 。これによると，3 階の場合に は耐力が小さいほど容易に非線形化するともに，長周期化によって 地震動の卓越周期（約 1 秒）に近づいていくためせん断変形角が急 増しや寸いことが, 1971 年以前の低層建物で, 中破以上の建物のう ち大破以上にまで被害が進展している建物が多いことと整合寸ると している。一方，9階と 12 階では非線形化しても長周期化によって 地震動の卓越周期からはずれて応答速度が減少するため, 応答変形 は大きく変化せずほぼ変位一定則が成り立っていた結果, 建物耐力 の有無が低層建物ほど被害に関係しなかったとしている。

林らの解析は 6 階以下の建物被害では建設年代の差が大きいのに 対して，7階以上の被害ではこの差が認められないことを説明して いるが，建物階数とせん断変形角との関係からは，6階よりも 9 階 と 12 階で変形角が小さくなっており,被害を必ずしも十分には説明 してはいないと考えられる。

\section{5. 新長田駅前市街地住宅の軽微な被害}

新長田駅前市街地住宅は強震動が観測された JR 鷹取の東約 $1 \mathrm{~km}$ の至近距離にあり, ともに兵庫県南部地震での震度 VIIの地域に含ま れている。この建物は地上 25 階, 地下 3 階の SRC 高層建物であり, 南北（桁行）方向は塔屋を除く全層で 14 スパン, 東西（張間）方向 は店舗・公共施設が入る地上 4 階までの低層部では 9 スパン，共同 住宅となっている 23 階までとレストランとなっている塔屋の高層 部では 3 スパンとなっている。地震直後の被災度区分判定では, 被 
災度は軽度と判定されている。主な被害は, 南北（析行）方向の中 廊下を構成する構面外の小梁と非構造壁に集中している。主要構造 部材のうち大梁については梁端部に曲げひび割れが認められ，柱に ついてもわずかな水平ひび割れが認められたが, その程度は軽微で ある。東西 (張間) 方向については, 構面の内外および構造部材, 非構造部材ともほとんど被害をうけていないとされている ${ }^{4)}$

兵庫県南部地震では 24 階と 5 階, 地下 1 階で地震動が記録されて いる。日下部ら ${ }^{23)}$ の解析結果によると, 24 階で観測された加速度記 録の速度応答スペクトルから, 建物は南北方向で 2.2 秒, 東西方向 で 2.0 秒が大きく卓越している。また, 建物の周期の約 1 秒から約 2 秒への伸びは, 建物の損傷に起因寸るとしている。ただし, 余震 では約 2 秒の振動は観測されていない。

この建物の被害と応答は木村ら ${ }^{24,25,26)}$, 津田ら ${ }^{27)}$, 沢井ら ${ }^{28)}$ によ って解析的に検討されている。これらの解析結果では, 複数階で大 梁の曲げ降伏が発生するなど被害の程度が実際よりも大きいと考え られる。そのため, この章では約 1 秒から 2 秒への建物の固有周期 の伸びは, 建物の損傷に起因しなくても発生しうることを検証する。

対象とする建物は地表面からの高さ $82 \mathrm{~m}$, 高層階部分の高さは $68.6 \mathrm{~m}$ であるが, 4 階以上は比重 1.8 の軽量コンクリートが使用され

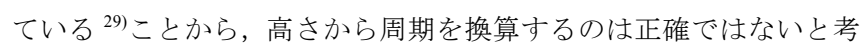
えられる。しかし, 表 1 に示寸ように過去の地震での卓越周期は報

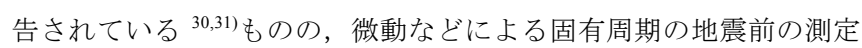
值は見当たらなかった。そこで, 前出の応答解析の論文を参考にす ると，いずれの解析とも固有周期は 1 秒程度であったことから，今 回の解析では沢井ら ${ }^{28)}$ にしたがって固有周期を1.06秒とした。なお, 表 1 に見られるように, 対象とする建物は兵庫県南部地震以前の強 震記録でも，建物周期の振幅依存性が認められている。

疑似弾性固有周期 $T_{P E}$ を 1.06 秒（設定固有周期 $T_{S E T}$ は 2.36 秒）と したときの, 鷹取（NS 成分）の 1 自由度質点系の加速度応答波形 のフーリエスペクトルを図 10 に示す。ここで, 減衰定数は前節と同 様に $5 \%$ （塑性減衰定数 $h^{\prime}=5.426 \%$ ）とし, 入力加速度波形は対象 とする建物の地下 1 階で観測された最大加速度 $356 \mathrm{Gal}^{32}$ にあわせて， 鷹取の入力波形の最大振幅がこの值になるよう波形全体の振幅を縮 小調整した。計算から得られた等価固有周期 $T_{E Q}$ は 2.29 秒, フーリ エスペクトルの卓越周期は 2.2 秒である。

図 10 には, 建物の 24 階で観測された南北方向の加速度波形のフ ーリエスペクトルも合わせて表示した。このスペクトルは木村ら ${ }^{24)}$ の論文から引用したもので, ハニングウインドウによる平滑化が加 えられている注4)。2つのスペクトルの卓越周期はほぼ一致している ことから, 兵庫県南部地震の際に南北方向で観測された 2.2 秒の固 有周期の伸びは, 建物の減衰機構が摩擦に起因する履歴減衰である ことによって生じる建物固有周期の遷移として説明できることにな る。もちろん，発生した固有周期の伸びの一部には建物の損傷も寄 与していることは, 建物の修復前後で微動の卓越周期が部分的に回 復している ${ }^{33)}$ ことに見られるが, 周期の伸びの大部分は減衰機構が 摩擦であることによる固有周期の遷移と考えることで, この建物の 被害が軽度であったことを説明することができる。図 8 に見られる ように, 鷹取のフラクタルスペクトルは擬似弾性固有周期が 1 秒以 上になると振幅は急激に減少している。この建物は固有周期が伸び ることで, 図 5 に見られる約 2 秒の卓越周期を越えられたことが,
表 1 新長田駅前住宅で兵庫県南部地震以前に観測された地震

\begin{tabular}{l|c|c|c|c}
\hline \multirow{2}{*}{ 地震名 } & \multicolumn{2}{|c|}{ 南北方向 } & \multicolumn{2}{c}{ 東西方向 } \\
\cline { 2 - 5 } & 周期 & 最大加速度 & 周期 & 最大加速度 \\
\hline 1983 年鳥取県沿岸地震 & $1.37 \mathrm{sec}$ & $102.78 \mathrm{Gal}$ & $0.97 \mathrm{sec}$ & $48.40 \mathrm{Gal}$ \\
\hline 1984 年山崎地震 & $1.28 \mathrm{sec}$ & $32.87 \mathrm{Gal}$ & $0.93 \mathrm{sec}$ & $40.51 \mathrm{Gal}$ \\
\hline 1985 年和歌山県北東部地震 & $1.28 \mathrm{sec}$ & $21.35 \mathrm{Gal}$ & $0.89 \mathrm{sec}$ & $15.19 \mathrm{Gal}$ \\
\hline
\end{tabular}

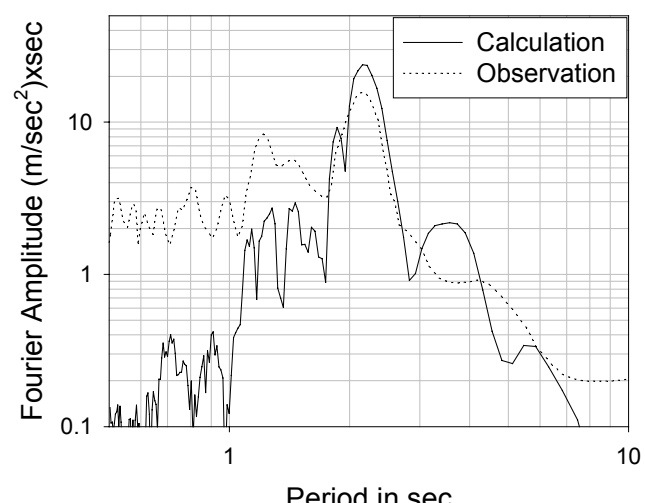

図 10 弾塑性 1 自由度質点系の応答と測定值のフーリエスペクトル （破線の観測值のフーリエスペクトルは木村ら ${ }^{24)}$ による）

軽微な被害にとどまることができた一因だと考えられる。

対象とする建物は損傷修復後, 地震観測装置を更新して観測が継 続されている。観測再開以降 2003 年 3 月末までの 50 の地震動を解 析した中村 ${ }^{34)}$ の報告によると, 層間変位が $1 / 1000$ 以下の小振幅であ っても変位振幅の増大に伴って固有振動数は低下し, 減衰定数は増 加する傾向が見られるとしている。24階で最大変位を示したのは 2000 年鳥取県西部地震の際の約 $4 \mathrm{~cm}$ であり,このときの南北方向の 固有周期と減衰定数は約 1.67 秒と約 $8 \%$ となっている。

\section{6. 芦屋浜高層住宅群での建物階数と被害との関係}

芦屋浜高層住宅が建設された当時は, ここで強震観測が行われて いたという報告 ${ }^{35)}$ があるが, 兵庫県南部地震の記録は見当たらない。 公表されている直近の強震記録は, 西に約 $2.2 \mathrm{~km}$ 離れた東神戸大橋 の深江浜で観測されたもので，地盤では GL-34m と GL-1.5m で記録

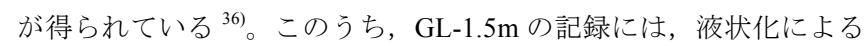
ものと考えられる強い非線形性が認められる。

芦屋浜高層住宅の北西約 $1.2 \mathrm{~km}$ の芦屋精道小学校では, 臨時観測 点で得られた余震記録を経験的グリーン関数とした本震記録の再現

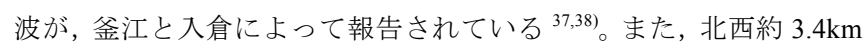
の神戸市立本山第一小学校では, 関西地震観測研究協議会による観 測結果が公開されている ${ }^{39)}$

前述したように，東神戸大橋の GL-1.5m での記録は液状化の影響 を強くうけている。芦屋浜高層住宅の敷地でも液状化は発生してい るが，地盤改良された建物周囲については全棟で夜状化現象は観察 されていない 5)。このため, 東神戸大橋の GL-34m での地震動を入 力とした芦屋浜の地盤での等価線形法による解析を行い, 応答スペ クトルを求めた。使用プログラムは(株) CRC ソリューションズによ ってパーソナルコンピュータ用に改修された SHAKE ${ }^{40)}$ である。

芦屋浜高層住宅の地盤断面図 ${ }^{41)}$ をとに作成した解析モデルを, 表 2 に示す。表層の埋立砂層は山砂と海砂によるもので, $\mathrm{N}$ 值が 15 を目標に地盤改良されている ${ }^{42)}$ 。この層の $\mathrm{S}$ 波速度は文献 35 の実 測值をもとに $200 \mathrm{~m} / \mathrm{sec}$ としたが, 土の動的物性は文献からは不明で 
あったため, 標準的な值 ${ }^{43}$ を採用した。3 層目以深の自然地盤につ いては, 芦屋浜の地層がポートアイランドの地層と対比でき ${ }^{44)}$, 層 序もよく似ていることから, $\mathrm{S}$ 波速度と土の動的物性はポートアイ

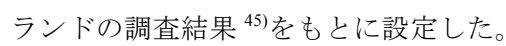

入力地震動は東神戸大橋の地盤で計算した入射波を採用すべきで あるが，この地震動では液状化した地盤の $\mathrm{S}$ 波速度と減衰を同定す ることができないという報告 ${ }^{46)}$ があることから， GL-34m の深度で ある層境界に観測波形をそのまま入力した。同じように液状化した 埋立地であるポートアイランドの解析では，GL-83m での観測波は ほぼ入射波とみなしうるという報告 ${ }^{46)}$ もるが，後述する 2 秒付近 の応答は観測波を入力波としたことによる影響の可能性がある。

図 11 に芦屋浜高層住宅の地盤での粘弾性応答スペクトル (Ashiyahama) と, 釜江と入倉による芦屋精道小学校での応答スペク トル $(\mathrm{ASY})^{38)}$, 本山第一小学校での応答スペクトル(Motoyama) ${ }^{39)}$ を示 寸注4)。減衰定数はすべて $5 \%$ である。

今回解析したスペクトルを釜江らのスペクトルと比較すると, 1.2 秒付近と 2 秒付近の卓越周期はよく一致している。しかし，スペク トルの振幅としては 2 秒付近の応答は釜江らの結果よりかなり大き くなっており，この周期での応答はやや過大に計算されている可能 性がある。観測值である本山のスペクトルは約 1 秒と 2 秒に卓越周 期が見られ, 約 1 秒の卓越周期は他の 2 つと比べるとやや短周期で あるが，比較的近いスペクトル形状を示している。これら 3 地点は いずれも地震断層が地表と交わる線の南東側にある ${ }^{47)}$ が, 扇状地上 の本山ではスペクトルの振幅が他より小さくなっている。そこで, 芦屋浜高層住宅群で推定される応答スペクトルとしては, 釜江らに よって再現された芦屋精道小学校 (ASY) と今回の解析結果 (Ashiyahama) をもとに，被害との関連を考察する。

芦屋浜高層住宅群は，1 フロア 4 戸の棟がエレベータを中心とし て 2 あるいは 3 棟が配置される構造となっている ${ }^{5}$ 。そのため, 振 動実験 (6) は, 棟単体での振動性状と棟相互の影響による振動性状の 把握を目的として, 単独あるいはできるだけ同じ階数の棟が隣接す る測定と，異なる階数の棟が隣接する測定が実施されている。測定 方法は常時微動と人力加振である。測定結果には隣接する他棟の影 響が見られ, 短辺方向の固有周期は 29 階では 1 棟より 2 棟の場合が, 24 階では 2 棟とそれ以上の棟の場合で, 後者の方が周期は長くなっ ている。短辺方向と長辺方向を含めた測定值から求められた周期 $T$ と高さ $H$ の実験公式は $T=0.02 H$ （標準偏差 $\sigma \mathrm{n}=0.0014 ）$ となってい る。また, 減衰定数は単独系の測定で, 1 次固有周期について $1.40 \%$ から $3.25 \%$ の範囲の值が報告されている。

芦屋浜高層住宅群の建物では, 兵庫県南部地震の損傷の補修効果 を確認するため, 常時微動が測定されている ${ }^{5)}$ 。ここでは建設当時 の固有周期に対して積載荷重による補正值が示されており, 図示さ れている 24 階建ての数值を目視で読み取ると, ほぼ $4 \%$ の周期の伸 びとなっている。建物の固有周期を建設当時の実験公式から求める と, 14 階 (高さ $40.58 \mathrm{~m})$ と 19 階 $(54.18 \mathrm{~m}), 24$ 階 $(69.04 \mathrm{~m}), 29$ 階 $(84.39 \mathrm{~m})$ の固有周期は 0.81 秒と 1.08 秒, 1.38 秒, 1.69 秒とな る。また, 積載荷重による効果がすべての建物タイプで $4 \%$ の増加 と仮定すると，それぞれ 0.84 秒と 1.13 秒， 1.44 秒，1.76 秒となる。

減衰定数として実測值の範囲である $1.40 \%$ から $3.25 \%$ の間でフラ クタル応答スペクトルを計算すると, 減衰定数が 3\% (塑性減衰定数
表 2 芦屋浜高層住宅の地盤解析モデル

\begin{tabular}{|c|c|c|c|c|c|c|c|}
\hline 層番号 & $\begin{array}{c}\begin{array}{l}\text { 層厚 } \\
\mathrm{m}\end{array} \\
\end{array}$ & 地層名 & 分割数 & \begin{tabular}{|l|} 
単位体積 \\
質量 $\mathrm{kg} / \mathrm{m}^{3}$ \\
\end{tabular} & \begin{tabular}{|c|} 
S波速度 \\
$\mathrm{m} / \mathrm{sec}$
\end{tabular} & \begin{tabular}{|l|} 
初期減 \\
衰率\% \\
\end{tabular} & 土の動的物性 \\
\hline 1 & 6.0 & 埋立砂 & 6 & 1800 & 200 & 2.0 & 今津雅紀，福武毅芳(文献42) \\
\hline 2 & 8.0 & 埋立砂 & 8 & 2000 & 200 & 2.0 & 今津雅紀, 福武毅芳(文献42) \\
\hline 3 & 4.0 & 沖積粘土 & 4 & 1750 & 180 & 2.0 & ポートアイランド19.0m〜19.75m \\
\hline 4 & 5.0 & 洪積砂礫 & 5 & 2000 & 245 & 2.0 & ポートアイランド $33.0 \mathrm{~m} \sim 34.0 \mathrm{~m}$ \\
\hline 5 & 1.0 & 洪積砂礫 & 1 & 2000 & 305 & 2.0 & ポートアイランド $33.0 \mathrm{~m} \sim 34.0 \mathrm{~m}$ \\
\hline 6 & 10.0 & 洪積砂礫 & 5 & 2000 & 305 & 2.0 & ポートアイランド $33.0 \mathrm{~m} \sim 34.0 \mathrm{~m}$ \\
\hline 7 & 基盤 & & & 2000 & 350 & & \\
\hline
\end{tabular}

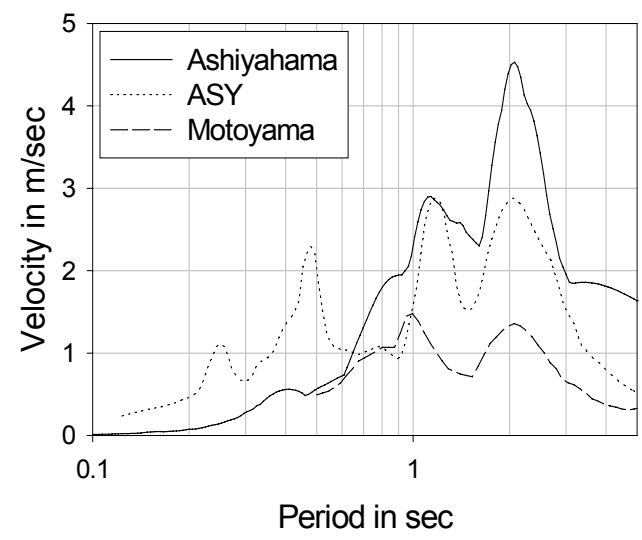

図 11 芦屋浜高層住宅と周辺での応答スペクトル（減衰定数 $5 \%$ ）

Ashiyahama : 今回の解析結果, ASY : 芦屋精道小学校での再 現結果 ${ }^{38)}$, Motoyama：本山第一小学校での観測結果 ${ }^{39)}$

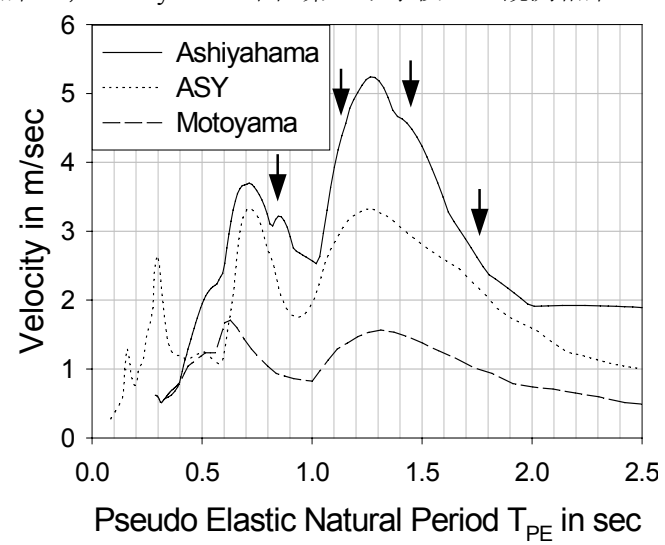

図 12 芦屋浜高層住宅と周辺でのフラクタル応答スペクトル 減衰定数 3\%,ASY と Motoyama は粘弾性応答からの換算 （図中の矢印は積載荷重の効果を考慮したときの固有周期）

$\left.h^{\prime}=3.148 \%\right)$ のときの結果が被害とよく対応する。図 12 にこの結果 を示寸。 $3 \%$ の減衰定数は $\mathrm{S}$ 造の一般的な減衰定数である $2 \%{ }^{22)}$ 上り やや大きいが, 大振幅時の応答であることと, 建物が初めて遭遇す るようなレベルの強震動であることから，ほぼ妥当であると考えら れる。芦屋精道小学校と本山第一小学校のスペクトルについては, 建築研究所の提案式 ${ }^{48)}$ に従って減衰定数が $5 \%$ から $3 \%$ のスペクト ルに変換したのち，（9）式で疑似弾性固有周期 $T_{P E}$ を求めた。

芦屋精道小学校（ASY）と今回の解析結果（Ashiyahama）を実験 式から求められる固有周期について比較すると, 24 階がもつとも振 幅が大きく次に 19 階となっており，29階で振幅が最小となってい る。14 階については, 今回の解析結果では 19 階よりも小さな振幅 であるが, 芦屋 (ASY) のスペクトルでは 19 階とほぼ等しくなって いる。ただし, 芦屋 (ASY) のスペクトルの形状はこの周期から長 周期側では急勾配で振幅が小さくなっており，積載荷重を考慮すれ ば 14 階の方が振幅は小さくなる。被害がなかった 14 階タイプのみ 
のブロックは公営棟であり ${ }^{41)}$, 他の 14 階タイプより短辺 (張間) 方向の長さが約 2 割程度短い5)ことからやや長周期である可能性が あること, 測定結果にもこの差が見られる ${ }^{6}$ ことから, これが 14 階 タイプでの被害の違いを説明するひとつの要因であるとも考えられ る。なお, 芦屋浜高層住宅群の被害について建物階数と被害との関 係を論じた報告を調べたが，個別の建物の損傷原因を解析した論文 はいくつか発表されているものの, 階数タイプによる被害率の違い を説明した論文は管見する限り見当たらなかった。

\section{7. まとめ}

建築物本体の減衰のメカニズムは摩擦に起因する履歴減衰である ことを与件とすると, 粘性減衰と同様に一定の減衰定数をもつ弾塑 性 1 自由度質点系では, 観測される固有周期は振幅によって変動す ることになる。振幅の増大によって建物の周期が伸びる現象は, 実 験や観測でも構造体が塑性化するよりはるかに小さな振幅レベルか ら確認されている。そこで, このような建物周期の伸びが強震動で の応答にも現れていると仮定し, 1 秒から 2 秒という兵庫県南部地 震の卓越周期との共振で被害事例が説明できるかを検討した。対象 とするのは建物固有周期の伸びであるが，周期の遷移が振幅の大き さに依存することから, 通常の応答スペクトルと長周期化した建物 の周期とを比較するのは容易ではない。このため, 一般的に建物の 固有周期が測定されている微小振幅を代表值として周期を変換した スペクトル（フラクタル応答スペクトル）をもとに, 地震動の卓越 周期と建物の固有周期とを比較した。

兵庫県南部地震では, 7 階以上のコンクリート系建物は 6 階以下 の建物に比べて明らかに被害率が大きかったが，減衰定数を $5 \%$ と した莫合のフラクタル応答スペクトルは 7 階の固有周期 0.38 秒から 振幅が急増しており，共振が被害率増大の原因と考えられる。

新長田駅前高層住宅では, 建物の 24 階で観測された地震動の卓越 周期は 2.2 秒と大きな周期の伸びが観測されたが, 被災度は軽度と 判定されている。弾塑性 1 自由度質点系の微小振幅時の周期を 1.06 秒, 減衰定数を $5 \%$ とし, 建物の地下で観測された最大加速度に振 幅調整した鷹取の応答波形は卓越周期が 2.2 秒となり, 構造材の降 伏を仮定しなくても周期の伸びが説明できることがわかった。

芦屋浜高層住宅群の例では，想定地盤での応答波形と釜江らによ る本震記録の再現波形から計算される減衰定数 $3 \%$ のフラクタル応 答スペクトルによると,ボックス柱破断の発生率が高かった 19 階と 24 階の周期では振幅が大きく, 破断のなかった 29 階の周期では振 幅は小さいという結果が得られた。

以上の解析例は, 兵庫県南部地震での特徴的な 3 例の被害は, 大 振幅のゆれによるほぼ弾性的な建物周期の伸びが地震動の卓越周期 と共振することによって発生したとする作業仮説を支持するもので ある。現在, 東南海地震と南海地震の発生がかなり切迫していると いう状況にあるが, 東京での長周期地震動の卓越周期は大多数の超 高層建物の弾性固有周期よりも長周期となっている。しかし，この 小論で論じた建物固有周期の遷移を考慮にいれると, 共振する建物 の評価についても新たな検討が求められると考えられる。

\section{謝辞}

解析にあたっては以下の 1995 年兵庫県南部地震の強震記録を使
用させていただきました。

1) 気象庁による神戸海洋気象台の記録，2）JR 西日本による鷹取駅 の記録，3）大阪ガスによる莫合供給所の記録と 4)阪神高速道路公 団による東神戸大橋の記録（震災予防協会の強震動アレー観測記 録データベース ${ }^{36,45)}$ による)

この報告は前報 ${ }^{12}$ に引き続き, 建物の減衰定数と固有周期の遷移 について考察したものです。ご議論いただいた東京大学名誉教授 の片山恒雄先生と, 常時微動の振幅についてご教授いただいた埼 玉大学名誉教授の小牧昭三先生に感謝いたします。また、粘弾性

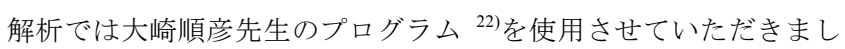
た。ここに記して感謝いたします。

\section{参考文献}

1) 林康裕ほか 3 名: 1995 年兵庫県南部地震における $\mathrm{RC}$ 造建物群の而震性能, 日本建築学会構造系論文集，No. 528，pp. 135-142，2000.2

2) 日本建築学会 : 建築物の減衰, 2000

3) 日本建築学会 : 建築構造物の振動実験, 1978

4) 阪神・淡路大震災調査報告編集委員会 : 阪神 - 淡路大震災調査報告, 鉄筋 コンクリート造建築物, pp. 394-399, 1997

5) 阪神・淡路大震災調査報告編集委員会 : 阪神 - 淡路大震災調査報告, 鉄骨 造建物, pp. 142-161, 1997

6) 田村良治ほか 7 名 : 芦屋浜高層住宅プロジェクト 高層住宅群の振動性状 に関する確認実験, 季刊カラム, No. 79, pp. 93-97, 1980

7) 境有紀ほか 3 名: 1999 年台湾集集地震に基づいた建物被害を予測する地震 動の破壊力指標の検討, 日本建築学会構造系論文集, No. 549, pp. 43-50, 2001.11

8) 境有紀ほか 2 名: 建物被害率の予測を目的とした地震動の破壊力指標の提 案, 日本建築学会構造系論文集, No. 555, pp. 85-91, 2002.5

9) 入倉孝次郎ほか 2 名 : 大加速度 (速度) 強震動の成因解明と強振動一地震 被害との相互関連性に関する研究, 地震研究所特定共同研究(B), $\langle$ http://www.eri.u-tokyo.ac.jp/KOHO/KOHO/backnumber/21/21-1.html〉, 1998 (アクセス : 2006 年 5 月 16 日)

10) 日本建築学会 : 兵庫県南部地震の強震動, 地震荷重一内陸直下地震によ る強震動と建築物の応答, pp. 63-91，2000

11) 鹿嶋俊英, 北川良和: 強震観測記録から推定した建物の振動特性の特徵, 日本建築学会技術報告集，第 22 号，pp. 163-166，2005

12) 小川好：減衰定数一定の弾塑性応答スペクトルに基づく建物固有周期の 遷移の解明, 日本建築学会構造系論文集, No. 600, pp. 75-82, 2006.2

13) Lagomarsino, S. : Forecast Models for Damping and Vibration Periods of Buildings, Journal of Wind Engineering and Industrial Aerodynamics, Vol. 48, pp. 221-239, 1993

14) 小川好, 岡田佳久: 地震動強度評価を目的とした弾塑性応答スペクトル の提案, 第 26 回地震工学研究発表会講演論文集, pp. 385-388, 2001

15) Iwan, W.D. : On a Class of Models for the Yielding Behavior of Continuous and Composite Systems, Journal of Applied Mechanics, Vol. 34, pp. 612-617, 1967

16) 曾田五月也ほか 3 名: 鋼構造物の減衰機構に関する実験的研究, 日本建 築学会大会学術講演梗概集, B2, pp. 1117-1118, 1999

17) 小泉忠由ほか 2 名：ボルト結合部における減衰能の評価，精密機械，46 巻, 3 号, pp. 338-343, 1980

18) Segalman, D. J. et al. : Handbook on Dynamics of Jointed Structures, SANDIA REPORT, SAND2009-4164, 2009

19) 吉本彰：コンクリートの変形と破壊，学献社，1990

20) 林康裕ほか 2 名: 建築物被害から推定される地震動強さと観測記録の整 合性，第 10 回日本地震工学シンポジウム, pp. 87-92, 1998

21) 日本建築学会 : 阪神・淡路大震災と今後の RC 構造設計, 丸善, pp. 12-14, 1998

22) 大崎順彦 : 新・地震動のスペクトル解析入門，鹿島出版会，p. 118，1994 23) 日下部馨ほか 3 名：兵庫県南部地震の激震地に建つ高層建物の観測地震 動, 構造工学論文集, Vol. 42B, pp. 15-22, 1996

24) 木村匡ほか 4 名: 兵庫県南部地震における新長田駅前高層 SRC 造建物の 解析的検討, その 1, 日本建築学会大会学術講演梗概集, B2, pp. 533-534, 1996

25) 竹内香織ほか 4 名: 兵庫県南部地震における新長田駅前高層 SRC 造建物 の解析的検討, その 2, 日本建築学会大会学術講演梗概集, B2, pp. 535-536, 1996 
26) 江戸宏彰ほか 4 名: 兵庫県南部地震における新長田駅前高層 SRC 造建物 の解析的検討, その 3, 日本建築学会大会学術講演梗概集, B2, pp. 537-538, 1996

27) 津田和明ほか 2 名：阪神・淡路大震災における被災建築物の地震応答解 析（2），大林組技術研究所報，特集号，pp. 85-91，1996

28) 沢井布兆ほか 3 名: SRC 造 25 階建て集合住宅の被害と解析, コンクリー 卜工学，Vol. 34, No. 11, pp. 37-41, 1996

29) 水畑耕治, 西出俊夫 : 細長い平面形を有する偏心高層建物の観測地震応 答の解析，日本建築学会大会学術講演梗概集，B，pp. 741-742，1986

30) 水畑耕治, 西出俊夫 : 昭和 58 年・鳥取県沿岸地震、及び昭和 59 年・山 崎地震による高層住宅の観測地震動について, 日本建築学会大会学術講演 梗概集，B，pp. 55-56，1985

31) 水畑耕治, 西出俊夫 : 昭和 60 年 1 月 6 日和歌山県北東部地震による高層 住宅の観測地震動について, 日本建築学会大会学術講演梗概集, B, pp. 853-854, 1986

32) 阪神 - 淡路大震災調查報告編集委員会 : 阪神 - 淡路大震災調査報告, 共 通編-2, 1 編 地震 ・地震動, pp. 230-233, 1998

33) Sawai et al : Response of a 25-story SRC Residential Building during the Hyogo-ken Nanbu Earthquake, Paper No. 1520, 11th World Conference on Earthquake Engineering

34) 中村充: SRC 造建物地震観測に基づく小振幅時動特性の振幅依存性評価, 日本建築学会大会学術講演梗概集, B2, pp. 949 - 950, 2003

35) 堯天義久ほか 6 名：芦屋浜における観測地震動の解析, 日本建築学会大 会学術講演梗概集, 構造系, pp. 547-548, 1981

36）震災予防協会：地震動アレー観測, No. 3, pp. 65-74, 1998

37) 釜江克宏, 入倉考次郎 : 1995 年兵庫県南部地震の断層モデルと震源近傍 における強震動シミュレーション, 日本建築学会構造系論文集, No. 500, pp. 29-36, 1997.10

38) 入倉考次郎：阪神大震災を引き起こした地震動, 京都大学防災研究所年 報，第 39 号，pp. 1-17， 1996

39) 日本建築学会：1995 年兵庫県南部地震強震記録資料集, p. 194, 1996
40) Schnabel, P.B. et al : SHAKE A Computer Program for Earthquake Response Analysis of Horizontally Layered Sites, EERC 72-12, UC Berkeley, 1972

41) 加藤裕造: 芦屋浜高層住宅プロジェクトにおける埋立地盤と基礎・地業, 建築と社会, 1977 年 8 月号, pp. 19-26, 1977

42) 相良巳貴夫 : 芦屋浜高層住宅プロジェクト，土と基礎，Vol. 26, No. 12,pp. 93-94, 1978

43) 今津雅紀, 福武毅芳: 砂碟材料の動的変形特性, 第 21 回土質工学研究発 表会, Vol. 1, pp. 509-512，1986

44) 阪神 - 淡路大震災調査報告編集委員会 : 阪神 - 淡路大震災調查報告, 共 通編一2，2編＼cjkstart地盤・地質，pp. 386-389，1998

45）震災予防協会 : 地震動アレー観測, No. 3, pp. 91-95, 1998

46) 阪神・淡路大震災調査報告編集委員会：阪神 - 淡路大震災調査報告，共 通編-2, 1 編 地震・地震動, pp. 298-301， 1998

47) 阪神・淡路大震災調查報告編集委員会：阪神 - 淡路大震災調査報告，共 通編-2, 1 編 地震・地震動, pp. 261-269, 1998

48) 伊藤浩資，笠井和彦：減衰定数による応答スペクトル低減に関する統計 的検討, 日本建築学会大会学術講演梗概集， B2, pp. 367-368, 2002

49) Hartwigsen, C. J. et al : Experimental Study of Non-linear Effects in a Typical Shear Lap Joint Configuration, J. of Sound and Vibration, 227, pp. 327-351, 2004 注

注 1）プログラムは粘性減衰定数も入力できるようになっているが，この論 文ではすべて 0 として計算している。

注 2） マイクロスリップの過程では，ジョイントを構成する部材間の移動は マクロレベルで見れば発生しておらず, 運動は接触面の小領域のみで発 生している ${ }^{49)}$ 。

注 3） 吉本 ${ }^{19}$ によると, 折れ点のうちの 2 点はコンクリート供試体に共通し て現れるが，不規則な折れ点はこれよりはるかに小さなひずみで出現す る。規則的な第 1 の折れ点は未水和セメント粒子の破壊に，第 2 折れ点 は供試体の容積が減少から増大に転じる臨界応力に対応するとしている。

注 4）図 10 の木村らによるスペクトルと, 図 11 の芦屋精道小学校と本山第 一小学校のスペクトルは目視による読み取りであり, 厳密ではない。

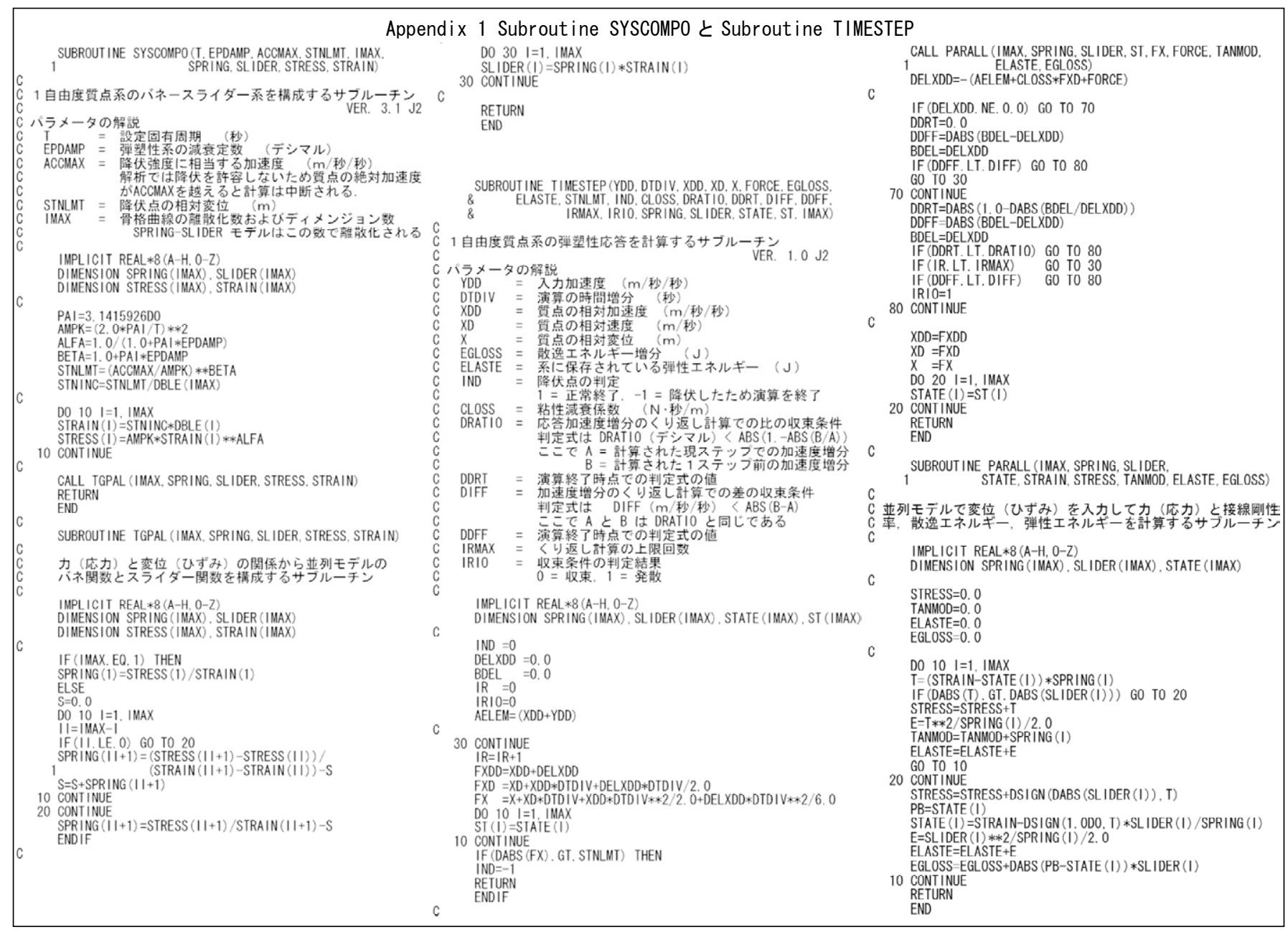

